\title{
SHIP HULL FOULING IN THE PORT OF RECIFE, PERNAMBUCO*
}

\author{
Cristiane Maria Rocha Farrapeira ${ }^{1^{* *}}$, Arthur Vinícius de Oliveira Marrocos de Melo, \\ Débora Ferreira Barbosa \& Karla Maria Euzebio da Silva \\ ${ }^{1}$ Universidade Federal Rural de Pernambuco - UFRPE \\ Departamento de Biologia \\ (Rua Dom Manoel de Medeiros, s/nº, Dois Irmãos, 52171-900 Recife, PE, Brasil) \\ **Corresponding author: c.farrapeira@db.ufrpe.br
}

\begin{abstract}
A B S TRACT
Ports of big coastal cities are exposed to exotic species as a consequence of shipping traffic. As the Port of Recife receives an annual average of 491 ships from other regions of Brazil and from all over the world, this work was aimed at knowing which marine animals were passively transported on such vessels hulls, in order to map and monitor new bioinvasions in the area. Thus, 32 vessels of several origins were investigated between November 2005 and March 2006, samples were taken and the macrofauna identified. Sixty species of associated animals were identified, consisting of 28 sessile species, particularly the Cirripedia Balanomorpha and Lepadomorpha as dominants, 8 sedentary animals, namely Mytillidae and Dreissenidae and 23 free-living species, particularly, Caprellidae, Gammaridae, Tanaidacea, Turbellaria, Nemertea and Polychaeta. The first occurrence of Conchoderma virgatum was recorded with exact location for the Brazilian littoral, and Conchoderma auritum, Amphibalanus subalbidus and Haliplanella lineata were recorded for the first time at the littoral of Pernambuco State. The invasion pathway was confirmed for Amphibalanus reticulatus and Mytilopsis leucophaeta, invader species of the estuarine area of Recife's city. Megabalanus coccopoma was considered as a risk invader species for the region.
\end{abstract}

\section{R ESUMO}

Regiões portuárias das grandes cidades litorâneas estão sujeitas à recepção de espécies exóticas como conseqüência da movimentação dos navios. Como o Porto do Recife recebe uma média anual de 491 atracações de navios, provenientes de várias regiões do Brasil e do mundo, objetivou-se conhecer quais animais marinhos eram transportados passivamente nos cascos das embarcações para mapear e monitorar novas invasões biológicas na área. Assim, foram investigados 32 barcos de diversas origens, nos meses de novembro de 2005 a março de 2006, tendo a macrofauna sido amostrada e identificada. Foram encontradas 60 espécies de animais associados, sendo: 28 espécies incrustantes, destacando-se os Cirripedia Balanomorpha e Lepadomorpha, como dominantes, 8 sedentárias, destacando-se os Mytillidae e Dreissenidae e 23 vágeis, sendo os principais: Caprellidae, Gammaridae, Tanaidacea, Turbellaria, Nemertea e Polychaeta. A primeira citação de Conchoderma virgatum foi registrada com localização exata para o litoral brasileiro, e Conchoderma auritum, Amphibalanus subalbidus e Haliplanella lineata foram registradas pela primeira vez para o litoral do estado de Pernambuco. O meio de dispersão foi confirmado para Amphibalanus reticulatus e Mytilopsis leucophaeta, espécies invasoras da área estuarina da Cidade do Recife. Megabalanus coccopoma foi considerada como espécie em risco de invasão para a região.

Descriptors: Vessels, Hull fouling, Bioinvasion, Biofouling, Barnacles, Port of Recife.

Descritores: Embarcações, Incrustação em cascos de navios, Bioinvasão, Bioincrustação, Cirrípedes, Porto do Recife.

\section{INTRODUCTION}

Fouling is a nautical and industrial term, subsequently adopted by marine ecologists, to refer to marine ecosystems consisting of organisms which attach to (epibionts), bore into (infauna) or otherwise live on hard natural or artificial substrata (Baker et al., 2004).

(*) Paper presented at the $1^{\text {st }}$ Brazilian Congress of Marine Biology, on 15-19 May 2006. Rio de Janeiro, Brazil.
Boulton et al. (1999) defined biofouling as commonplace on immersed marine structures, including the hulls of vessels such as harbor ferries, which are in routine commercial service. The economic costs caused by the presence of biofoulers, such as barnacles, mussels and algae on the underwater hulls of ships are high, because the weight or burrowing activity of the organisms can damage structures, clog intakes and slow vessels, resulting in expensive dry-docking, increased drag, higher fuel 
consumption and corrosion (Clarke, 1995; Baker et al., 2004; Floerl, 2005). Invasions by non-indigenous species are a major force of global change, resulting in significant ecological, economic, and human health impacts.

Marine biological invasions brought about by anthropogenic influences have occurred throughout the world through a variety of mechanisms including shipping, aquaculture; live seafood and bait shipments; the activities of commercial, educational and research aquariums; biocontrol and human-created canals (Ruiz et al., 2000; Godwin, 2003). There are other pathways associated with maritime vessel activity that can be responsible for introductions. Some new arrivals are probably dispersed naturally by oceanic currents carrying larvae or adults, but this mode of dispersal is virtually impossible to confirm (Forster \& Willan, 1979).

The ocean-going vessels can be thought of as "biological islands" for species that dwell in harbors and estuaries, since they provide substrate for the settlement of species associated with fouling communities (Godwin, 2003). Fouling on vessel hulls creates entirely new transfer pathways for biological communities across substantial biogeographical barriers, and the dispersal of marine organisms by shipping has long been used in interpreting the biogeography of marine invertebrates, often in retrospect once a foreign species is found established (Foster \& Willan, 1979; Carlton \& Geller, 1993). In fact, the primary pathway identified for marine nonindigenous organisms introductions has been maritime vessel traffic to ports around the world by the biofouling on ships, but the transport of organisms in ballast water has also been recognized as the major vector for the inadvertent transfer of many shallow water benthic non-indigenous and harmful organisms around the globe (Carlton \& Geller, 1993; Ruiz et al., 2000; Godwin \& Eldredge, 2001; Gollasch, 2002; Coutts \& Taylor, 2004).

When in a new environment, introduced animals can compete with native ones for food or space resulting in high population densities and large body sizes. They can also introduce new pests, parasites, or pathogens, because they may bring with them all or a subset of their native parasite fauna, and microbial infections, and generally cause a disruption to the native environment (DeFelice et al., 2001; Torchin et al., 2001; 2003).

The transport of non-indigenous species by commercial shipping typically results in port environments becoming major points of biotic invasion, with a greater density and diversity of organisms (Wasson et al., 2001; Hewitt et al., 2004). Vessels acquire the majority of hull fouling while moored in coastal ports, these environments acting as hubs of domestic and international shipping movements (Carlton, 1987). Stationary vessels provide substrate for the settlement of fouling species, including protected recesses that can be occupied by both sessile and mobile fauna (Godwin, 2003).

Pernambuco State lies in the South Atlantic Ocean, in a region of tropical climate. In recent years, there have been occurrences of aquatic invaders, including the false dark mussel Mytilopsis leucophaeta, and the swimming crab Charybdis hellerii, both introductions assumed to be via ships' ballast water (Souza et al., 2005; Tavares \& Mendonça, 1996; Coelho \& Santos, 2003), and the barnacles Striatobalanus amaryllis and Amphibalanus reticulatus, assumed to be via hull biofouling.

On the basis of the above considerations, and that the Port of Recife receives ships of many kinds proceeding from other regions of Brazil and other countries of the world, a survey was planned and conducted with the following main objectives of establishing the identity, frequency of occurrence and distribution of the predominant animals' species associated with the various shipping trade routes, and then to know which ones are carried passively by vessels that arrive in the port in order to map and monitor new biological invasions in the area.

\section{Port of Recife Area}

The Port of Recife is located in the city of Recife, on the coast of the State of Pernambuco, northeastern Brazil, between $08^{\circ} 04^{\prime} 03^{\prime \prime}-08^{\circ} 05^{\prime} 06^{\prime \prime} \mathrm{S}$ and $34^{\circ} 52^{\prime} 16^{\prime \prime}-34^{\circ} 53$ ' $58^{\prime \prime} \mathrm{W}$, in the estuarine area of the Capibaribe and Beberibe Rivers and Pina Basin (Fig. 1). The area has a hot and humid tropical climate, with annual average air and water temperatures around $25^{\circ} \mathrm{C}$, annual thermal amplitude of the water around $7^{\circ} \mathrm{C}$ (minimum 24 and maximum of $31^{\circ} \mathrm{C}$ ); relative humidity of the air around $80 \%$ to $90 \%$ and annual rainfall varying from $1760 \mathrm{~mm}$ to $2270 \mathrm{~mm}$, with $80 \%$ of rain falling between April and July, corresponding to the winter months. The maximum (extreme spring tides) tidal height at the port is $3.11 \mathrm{~m}$, with an annual high tide average of $2.60 \mathrm{~m}$ in syzygy and $1.60 \mathrm{~m}$ in neap tides, respectively. There are two access channels to the Port, both natural. The main one, South Channel, is approximately $260 \mathrm{~m}$ wide and $3.4 \mathrm{~km}$ long with a depth of $10.5 \mathrm{~m}$. The other one, North Channel, narrower, with ca. $1.0 \mathrm{~km}$ long and a depth of $6.5 \mathrm{~m}$, is employed only by smaller vessels. Currently the Port of Recife receives an annual average anchorage of 491 ships mainly freighters, but also container ships, research and training vessels, freezer ships, navy vessels, passenger/tourist liners, fishing boats, oil tankers and others (Port of Recife, 2006). 


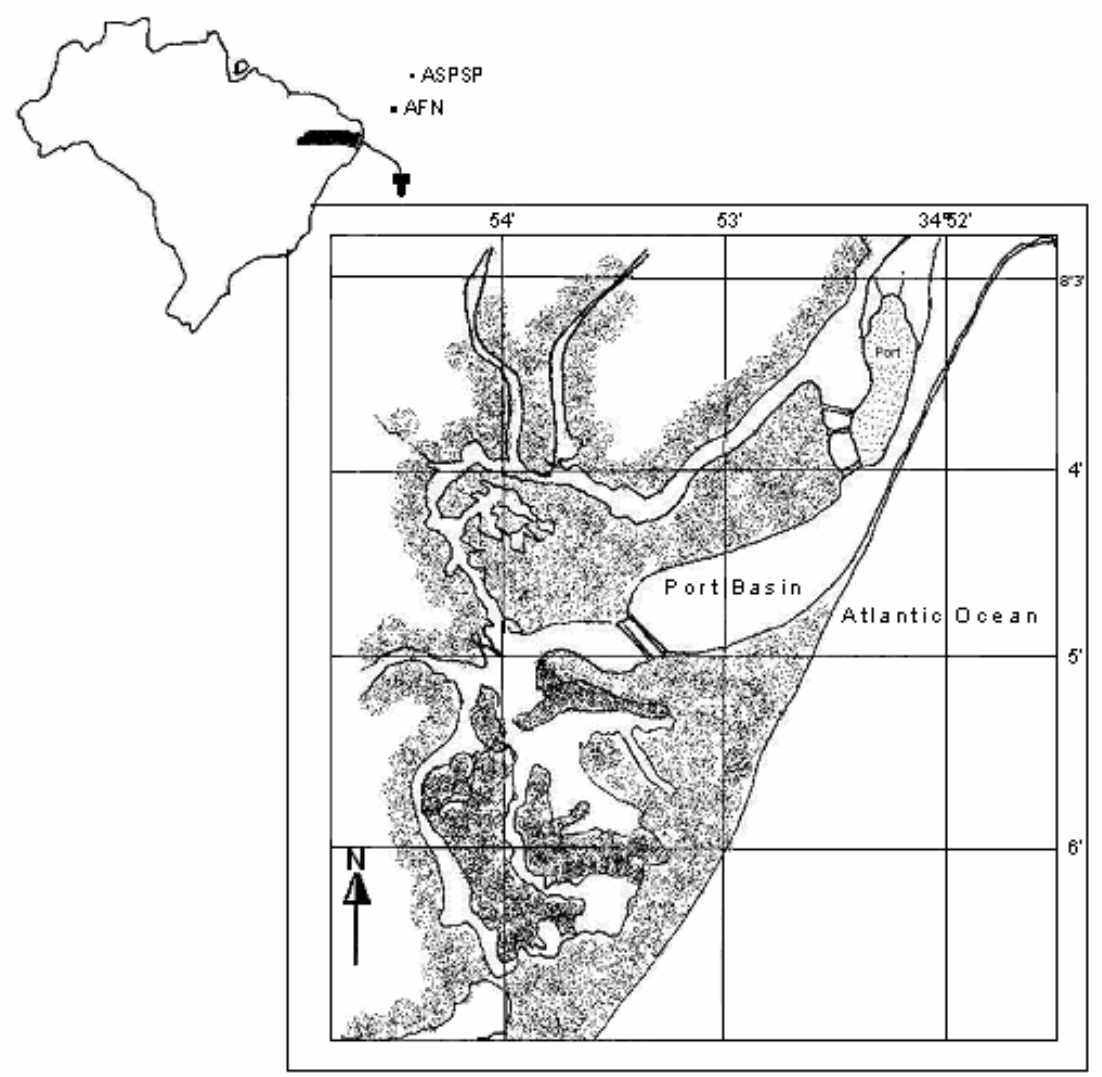

Fig. 1. Location of the Port of Recife and Brazilian archipelagos in the South Atlantic Ocean: AFN= Archipelago Fernando de Noronha, ASPSP= Archipelago São Pedro e São Paulo (Port area scale; 1:25.000).

\section{Material And Methods}

Between November 2004 and April 2006, fortnightly samples of fouling organisms were collected from all vessels arriving to the Port of Recife, Pernambuco. Material was scraped by spatula and hammer on the submerged parts and wave-splash zone from as many different areas of the hull as required for a representative sampling, looking for the different morpho-species and collecting them in a plastic bag. Although seaweed had been collected, they had not been object of study of the present research. The animals were fixed in $4 \%$ formalin and identified under stereomicroscopy using the pertinent literature. Some organisms could not be identified to species level due to taxonomic difficulties with their groups, and such results are presented at a higher taxon level.

Information on the nature and provenance of the ships and boats was either obtained directly, either asking the crew members or from the shipping agents that handled each vessel or consulting the daily bulletin board on the website of the Port of Recife (Port of Recife, 2006). During the samplings, salinity was measured by a portable densimeter.

Since it is difficult to make a fully quantitative assessment of the fouling growth on a ship's hull, a more subjective appraisal of fouling intensity was adopted. Thus, records show firstly the different species found on ships of various types and secondly, the number of these ships on which each species was regarded as an important component of the various fouling assemblages. To monitor these biofouling communities, some boats were investigated several times (mainly vessels coming from the Brazilian archipelagos), but these are only represented once in the Tables. Observations were made on organisms' reproductive status whenever possible, by considering the gonad development or the presence of incubated eggs or larvae. 
In this paper fouling organisms were considered to be any sessile or sedentary species which attach to hard substrates, both natural and manmade. To present the results, the following terms and definitions were used, summarized from Eno et al. (1997) and Clarke et al. (2004):

- $\quad$ Native (N) species with a long natural presence in the region, that may extend into the pre-historic record;

- Cryptogenic (C) species that are neither demonstrably native nor introduced, in other words, their native range is uncertain;

- Exotic (E) species that have been transferred by human activity into a region beyond their natural range or natural zone of potential dispersal;

- Invasive (I) species, an established introduced species that spreads rapidly through a range of natural or semi-natural habitats and ecosystems, mostly by its own means;

- Risk (R) species likely deemed to become harmful if introduced to a region beyond their natural range, as based on inductive evaluation of available evidence.

\section{RESULTS}

Incidence of Fouling Species on Vessels

Fouling organisms were sampled from the hulls of 32 vessels. A total of 60 species were recorded, representing 9 animals phyla: 3 species of Cnidaria (1 hydroid and 2 anemones), 1 Platyhelminthes (flatworm), 1 Nematoda, 1 Nemertea, 7 Annelida (marine worms), 15 Mollusca (3 oysters, 5 mussels, 6 snails and 1 vermetids), 33 Arthropoda (1 Insecta chironomid, 1 Pycnogonida and 31 Crustacea- 19 barnacles, 1 tanaidaces, 3 amphipods, 2 isopods and 6 crabs), 2 Polyzoa (moss animals) and 2 Chordata [subphylum Urochordata] (sea squirts) (Fig. 2).

Eight types of vessels were investigated that were stationary or temporarily moored in the Port of Recife including 12 fishing, 9 cargo, 6 tugboat, 2 research, 2 pilot, 1 dredger and 1 sail ship. Table 1 shows the species or taxa identified, indicating the type of vessels where they were found and the organisms' status (as native, cryptogenic, exotic, and risk species) with regard to the Port of Recife.

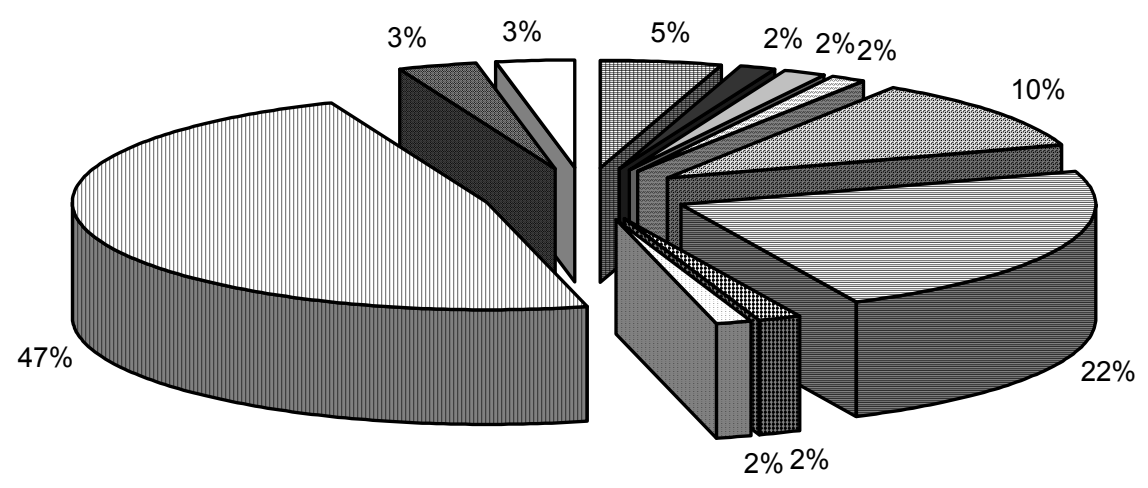

\begin{tabular}{|c|c|c|c|}
\hline घCNIDARIA & 口TURBELLARIA & 口NEMATODA & 口NEMERTEA \\
\hline 口POLYCHAETA & GMOLLUSCA & DINSECTA & 口PYCNOGON \\
\hline 口CRUSTACEA & 口POLYZOA & 口TUNICATA & \\
\hline
\end{tabular}

Fig. 2. Taxon groups represented in the hull fouling communities of the Port of Recife vessels, showing the number of species (total 60 species). 
Table 1. Checklist of species sampled on the hulls of eight vessels' types (sail, cargo, fishing, dredger, research, tugboat, pilot, and moored ship) operating in the Port of Recife, Pernambuco, Brazil. $\mathrm{N}=$ native; $\mathrm{C}=$ cryptogenic; $\mathrm{E}=$ exotic; $\mathrm{I}=$ invasive; $\mathrm{R}=$ risk (all of them considering the Northeast region of Brazil).

\begin{tabular}{|c|c|c|c|c|c|c|c|c|c|}
\hline TAXON / SPECIE & OBS & SAIL & CARGO & FISHING & DREDGER & RESEARCH & TUG & PILOT & MOORED \\
\hline OBSERVED NUMBER & & 1 & 7 & 11 & 1 & 2 & 4 & 2 & 5 \\
\hline Hydroida unidentified & & & 2 & 2 & 1 & 1 & & & 3 \\
\hline Aiptasia pallida & $\mathrm{E}$ & & & 2 & & & & & 2 \\
\hline Haliplanella lineata & E & & & & & & & & 2 \\
\hline NEMATODA & & & & 4 & & 2 & 1 & 1 & 4 \\
\hline NEMERTEA & & & 2 & 3 & 1 & & 2 & & 3 \\
\hline Distylochus martae & E & & 2 & 2 & & 1 & 2 & 1 & 3 \\
\hline Polychaeta unidentified. & & & 3 & 6 & & 1 & 2 & 2 & 4 \\
\hline Hydroides sp & & & 2 & 3 & 1 & & & & \\
\hline Brachidontes exustus & $\mathrm{N}$ & & & 1 & & & & & \\
\hline Brachidontes solisianus & $\mathrm{N}$ & & 1 & 1 & & 1 & 1 & 1 & 4 \\
\hline Crassostrea rhizophorae & $\mathrm{N}$ & & 1 & 2 & 1 & 1 & & & 3 \\
\hline Isognomon bicolor & E & & & 1 & 1 & 1 & & & \\
\hline Mytella charruana & $\mathrm{N}$ & & 3 & 3 & & 1 & 1 & 1 & 5 \\
\hline Mytella guyanensis & $\mathrm{N}$ & & & 1 & & & & & 3 \\
\hline Mytilopsis leucophaeta & I & & 2 & 1 & & & 3 & 1 & 5 \\
\hline Ostrea equestris & $\mathrm{N}$ & & 1 & 1 & & 1 & & 1 & 1 \\
\hline Colisella subrugosa & $\mathrm{N}$ & & & & & 1 & & & \\
\hline Littorina angulifera & $\mathrm{N}$ & & 2 & 2 & & & 1 & 1 & 3 \\
\hline Littorina flava & $\mathrm{N}$ & & 1 & 2 & & & & & \\
\hline Nodilittorina ziczac & $\mathrm{N}$ & & & & & 1 & & & \\
\hline Melanoides tuberculata & E & & & 1 & & & & & \\
\hline Neritina zebra & $\mathrm{N}$ & & & 1 & & & & & \\
\hline Vermetidae unidentified & & & & 1 & & & & & \\
\hline Pycnogonida unidentified & & & & 2 & & & & & 1 \\
\hline Chironomidae & & & & 1 & & & & & 3 \\
\hline Amphibalanus amphitrite & $\mathrm{C}$ & & 5 & 5 & 1 & 1 & 2 & 2 & 5 \\
\hline Amphibalanus eburneus & $\mathrm{C}$ & & 1 & 3 & 1 & & 1 & 1 & 4 \\
\hline Amphibalanus improvisus & C & 1 & 5 & 7 & & 1 & 3 & 2 & 5 \\
\hline Amphibalanus reticulatus & $\mathrm{E}$ & & 1 & 3 & 1 & 1 & 1 & 2 & 4 \\
\hline Amphibalanus subalbidus & $\mathrm{E}$ & & & & 1 & & & & 1 \\
\hline Balanus trigonus & $\mathrm{C}$ & & 2 & 2 & 1 & 1 & & & \\
\hline Chthamalus proteus & $\mathrm{N}$ & & & 5 & & 2 & & 2 & 1 \\
\hline Euraphia rhizophorae & $\mathrm{N}$ & & & & & 1 & & & \\
\hline Megabalanus соссорота & $\mathrm{R}$ & & 1 & 2 & & & & & \\
\hline Megabalanus tintinnabulum & $\mathrm{C}$ & & & 5 & 1 & 1 & 1 & 1 & \\
\hline Megabalanus vesiculosus & $\mathrm{N}$ & & & & & 2 & & & \\
\hline Striatobalanus amaryllis & $\mathrm{E}$ & & & & & & & & 1 \\
\hline Tesseropora sp & & & & & & & & 1 & \\
\hline Tetraclitidae unidentified & & & & 2 & & & & & \\
\hline Conchoderma auritum & $\mathrm{E}$ & & & 4 & & & & & \\
\hline Conchoderma virgatum & E & 1 & & 5 & & & & & 1 \\
\hline Lepas anatifera & $\mathrm{C}$ & 1 & & 5 & & 1 & & & \\
\hline Lepas anserifera & $\mathrm{C}$ & 1 & & 3 & & & & & \\
\hline
\end{tabular}


Table 1. (continued)

\begin{tabular}{|c|c|c|c|c|c|c|c|c|c|}
\hline TAXON / SPECIE & OBS & SAIL & CARGO & FISHING & DREDGER & RESEARCH & TUG & PILOT & MOORED \\
\hline OBSERVED NUMBER & & 1 & 7 & 11 & 1 & 2 & 4 & 2 & 5 \\
\hline Lepas hillii & $\mathrm{C}$ & 1 & & 5 & & & & & \\
\hline Alcirona unidentified & & & 2 & & & & & & 2 \\
\hline Ligia exotica & $\mathrm{N}$ & & 1 & 2 & & 1 & & & 2 \\
\hline Caprella equilibra & $\mathrm{C}$ & & & 1 & & & & & 3 \\
\hline Caprella $\mathrm{sp}$ & & & & 1 & & & & & \\
\hline Gammaridae unidentified & & & 2 & 1 & 1 & 2 & & 1 & 4 \\
\hline Tanaidacea unidentified & & & 2 & 5 & & 1 & 1 & 2 & 5 \\
\hline Aratus pisonii & $\mathrm{C}$ & & & 1 & & & & & \\
\hline Pachygrapsus gracilis & $\mathrm{C}$ & & & 2 & & & 1 & 1 & 3 \\
\hline Pachygrapsus transversus & $\mathrm{C}$ & & & 1 & & & & & \\
\hline Panopeus lacustris & $\mathrm{N}$ & & & & & & & & 1 \\
\hline Petrolisthes armatus & $\mathrm{N}$ & & & & & & & & 2 \\
\hline Plagusia depressa & $\mathrm{N}$ & & 1 & 1 & & & & & \\
\hline Bowerbankia sp & & & & 3 & & 1 & & 1 & \\
\hline Membranipora $\mathrm{sp}$ & & & & & & 1 & & & 1 \\
\hline Styela plicata & $\mathrm{E}$ & & & 1 & 1 & 1 & & & \\
\hline Ascidian unidentified & & & & 1 & & 1 & & & \\
\hline
\end{tabular}

In the sampling period, the salinity of the harbor area varied from 20 at low tide) to 35 at high tide.

Vessels with Long-term Moorings to the Port of Recife

Three cargo ships and two tugboats out of commission, anchored in the Port of Recife for more than one year were inspected. They showed the typical fouling community of the estuarine euhaline area of the Port basin, with severe fouling in almost all vessels. Thirty seven species of animals were identified, including the following exotics: the anemone Haliplanella lineata and barnacle Striatobalanus amaryllis (found only in two of these boats), the flatworm Distylochus martae, the false dark mussel Mytilopsis leucophaeta, and the barnacles Amphibalanus reticulatus, $A$. subalbidus and Conchoderma virgatum (Table 2).

Mussels (Mytella charruana and Mytilopsis leucophaeta) and barnacles (Amphibalanus amphitrite and $A$. improvisus) were found on all vessels moored long-term in the Port of Recife and were numerically dominant, with Nematoda and Tanaidacea as accompanied fauna. Considerable mortality of barnacles was evident on the steel substrate of the "Mercurius" and "Saveiros" tugboats, out of service since 1991. Curiously, these tugboats have a band of settlement of Striatobalanus amaryllis (all of them dead) and Amphibalanus reticulatus (the majority dead), with flatworms (Distylochus martae) and Chironomiidae larvae and pupae inside the barnacle shells. These tugboats were sunk in the littoral of
Recife in April 2006, to provide an artificial reef (as fishing attraction).

Somewhat similar results were recorded on the Greek ship originally called "Kings Town" (presently in repair, with the new name "Michail Archangelo"), out-docked since September 1999, that had several indigenous species of the Pernambuco coast, mainly present in the harbor basin and estuarine area of Recife, in the euhaline regions. These included Amphibalanus amphitrite, A. eburneus, A. improvisus, Mytella charruana and a heavy settlement of the recent introduced and invasive species, Mytilopsis leucophaeta. The same community was observed at the "Zeus" tugboat moored to the Port since October 2003 (which was cleaned in March 2006 and is now operating in the coastal harbor area); the fishing boat "Tontini" (now called "Santa Evita"), moored since July 1999 and the cargo ship "Arcanjo Anjo Gabriel", from the Fernando de Noronha Archipelago, moored to the port since May 2005.

Vessels Limited to the Neighborhood of the Port of Recife

Fouling on seven vessels with their itinerary around the Port of the Recife region including: two pilot boats, one fishing boat and four tugboats were also investigated. Twenty six species of fouling animals were identified, including the following exotics animals: the flatworm Distylochus martae, the false dark mussel Mytilopsis leucophaeta, and the barnacle Amphibalanus reticulatus. The barnacle $A$. improvisus was numerically dominant and present on all boats. A noteworthy finding was a species of Tesseropora as yet unidentified (Table 3 ). 
Table 2. Checklist of fouling species observed on the hulls of five vessels moored long-term in the Port of Recife, Pernambuco, Brazil. $\mathrm{X}=$ present; $\mathrm{XX}=$ numerically dominant on the vessel's hull; * in reproduction.

\begin{tabular}{|c|c|c|c|c|c|}
\hline VESSEL & Arcanjo Anjo Gabriel & Mercurius and Saveiros & $\begin{array}{c}\text { Michail } \\
\text { Archangelo }\end{array}$ & Santa Evita & Zeus \\
\hline MOORED SINCE & $23 / 4 / 2005$ & 1991 & $30 / 9 / 1999$ & 19/7/1998 & 6/10/2003 \\
\hline TYPE & Cargo & Tug & Cargo & Cargo & Tug \\
\hline Hydroida & $\mathrm{x}$ & $\mathrm{x}$ & & & \\
\hline Aiptasia pallida & & $\mathrm{xX}$ & & & $\mathrm{XX}$ \\
\hline Haliplanella lineata & $\mathrm{X}$ & $\mathrm{X}$ & $\mathrm{x}$ & & \\
\hline Distylochus martae & $\mathrm{XX}$ & $\mathrm{XX}$ & $\mathrm{XX}$ & & $\mathrm{XX}$ \\
\hline Nematoda & $\mathrm{XX}$ & $\mathrm{XX}$ & $\mathrm{XX}$ & $\mathrm{xX}$ & $\mathrm{XX}$ \\
\hline Nemertea & $\mathrm{XX}$ & $\mathrm{XX}$ & & & $\mathrm{x}$ \\
\hline Polychaeta & $\mathrm{X}$ & & $\mathrm{XX}$ & $\mathrm{xX}$ & $\mathrm{XX}$ \\
\hline Littorina angulifera & $\mathrm{x}$ & & $\mathrm{x}$ & & $\mathrm{x}$ \\
\hline Brachidontes exustus & & & $\mathrm{x}$ & & \\
\hline Brachidontes solisianus & $\mathrm{x}$ & & $\mathrm{x}$ & $\mathrm{x}$ & $\mathrm{x}$ \\
\hline Crassostrea rhizophorae & $\mathrm{X}$ & $\mathrm{X}$ & $\mathrm{X}$ & & \\
\hline Mytella charruana & $\mathrm{XX}$ & $\mathrm{XX}$ & $\mathrm{XX}$ & $\mathrm{XX}$ & $\mathrm{XX}$ \\
\hline Mytella guyanensis & & $\mathrm{x}$ & $\mathrm{x}$ & & $\mathrm{x}$ \\
\hline Mytilopsis leucophaeta & $\mathrm{XX}$ & $\mathrm{XX}$ & $\mathrm{XX}$ & $\mathrm{xX}$ & $\mathrm{XX}$ \\
\hline Ostrea equestris & & & $\mathrm{X}$ & & \\
\hline Chironomidae & $\mathrm{XX}$ & $\mathrm{XX}$ & $\mathrm{XX}$ & & \\
\hline Pycnogonida & & & $\mathrm{x}$ & & \\
\hline Amphibalanus amphitrite & $\mathrm{XX}$ & $\mathrm{XX}$ & $\mathrm{XX} *$ & $\mathrm{XX} *$ & $\mathrm{XX} *$ \\
\hline Amphibalanus eburneus & $\mathrm{XX}$ & $\mathrm{XX}$ & $\mathrm{XX}$ & & $\mathrm{X}$ \\
\hline Amphibalanus improvisus & $\mathrm{XX} *$ & $\mathrm{XX}$ & $\mathrm{XX}$ & $\mathrm{XX}$ & $\mathrm{XX}^{*}$ \\
\hline Amphibalanus reticulatus & $\mathrm{x}$ & $\mathrm{X}$ & $\mathrm{x}$ & & $\mathrm{XX}$ \\
\hline Amphibalanus subalbidus & $\mathrm{X}$ & & & & \\
\hline Chthamalus proteus & $\mathrm{x}$ & & & & \\
\hline Conchoderma virgatum & & & & $\mathrm{X}$ & \\
\hline Euraphia rhizophorae & & & $\mathrm{x}$ & & \\
\hline Striatobalanus amaryllis & & $\mathrm{X}$ & & & \\
\hline Caprella equilibra & & $X^{*}$ & & $X^{*}$ & $\mathrm{x}$ \\
\hline Caprella $s p$ & & $\mathrm{X}$ & & & \\
\hline Amphipoda Gammaridae & $\mathrm{XX}$ & $\mathrm{x}$ & $\mathrm{XX}$ & & $\mathrm{x}$ \\
\hline Alcirona $\mathrm{sp}$ & $\mathrm{x}$ & & $\mathrm{x}$ & & \\
\hline Ligia exotica & $\mathrm{X}$ & & & $\mathrm{X}$ & \\
\hline Tanaidacea & $\mathrm{X}^{*}$ & $\mathrm{XX} *$ & $\mathrm{XX}$ & $\mathrm{x}$ & $\mathrm{XX} *$ \\
\hline Pachygrapsus gracilis & $\mathrm{XX}^{*}$ & & $\mathrm{XX}$ & $\mathrm{XX}$ & \\
\hline Panopeus lacustris & $\mathrm{X}$ & & & & \\
\hline Petrolisthes armatus & $\mathrm{X} *$ & & $\mathrm{x}$ & & \\
\hline Membranipora sp & & $\mathrm{x}$ & & & \\
\hline
\end{tabular}


Table 3. Checklist of fouling species observed on the hulls of six vessels operating in the Port of Recife area, Pernambuco, Brazil. $\mathrm{X}=$ present; $\mathrm{XX}=$ observed as numerically dominant on the vessel's hull; $*=$ in reproduction.

\begin{tabular}{|c|c|c|c|c|c|c|c|}
\hline VESSEL & Serrambi & 28 September & Horizonte 1 & Cygmus & Polaris & Scorpius H2G & Zeus \\
\hline TYPE & Pilot & Pilot & Fishing & Tug & Tug & Tug & Tug \\
\hline Hydroida & & & $\mathrm{x}$ & & & & \\
\hline Aiptasia pallida & $\mathrm{x}$ & & & & & & \\
\hline Distylochus martae & $\mathrm{X}$ & & $\mathrm{X}$ & $\mathrm{X}$ & & $\mathrm{XX}$ & $\mathrm{X}$ \\
\hline Nematoda & & $\mathrm{XX}$ & $\mathrm{xX}$ & & & $\mathrm{XX}$ & \\
\hline Nemertea & & & $\mathrm{xx}$ & $\mathrm{X}$ & & $\mathrm{xX}$ & $\mathrm{X}$ \\
\hline Polychaeta & $\mathrm{x}$ & $\mathrm{XX}$ & $\mathrm{x}$ & $\mathrm{XX}$ & & $\mathrm{XX}$ & $\mathrm{x}$ \\
\hline Littorina angulifera & $\mathrm{X}$ & $\mathrm{X}$ & & & & $\mathrm{X}$ & \\
\hline Brachidontes solisianus & & $\mathrm{x}$ & & & & $\mathrm{x}$ & \\
\hline Crassostrea rhizophorae & & & $\mathrm{x}$ & & & & \\
\hline Mytella charruana & $\mathrm{x}$ & $\mathrm{x}$ & $\mathrm{x}$ & & & $\mathrm{x}$ & \\
\hline Mytella guyanensis & & & $\mathrm{X}$ & & & & \\
\hline Mytilopsis leucophaeta & & $\mathrm{x}$ & & $\mathrm{XX}$ & $\mathrm{XX}$ & $\mathrm{x}$ & \\
\hline Ostrea equestris & & $\mathrm{x}$ & & & & & \\
\hline Amphibalanus amphitrite & $\mathrm{XX}$ & $\mathrm{xX}$ & & $\mathrm{XX}$ & & $\mathrm{XX} *$ & $\mathrm{X}$ \\
\hline Amphibalanus eburneus & & $\mathrm{x}$ & & & & $\mathrm{x}$ & \\
\hline Amphibalanus improvisus & $\mathrm{XX} *$ & $\mathrm{xX}$ & $\mathrm{x}$ & $\mathrm{XX}$ & $\mathrm{XX}$ & $\mathrm{XX}$ & \\
\hline Amphibalanus reticulatus & $\mathrm{XX} *$ & $\mathrm{x}$ & & & & $\mathrm{XX} *$ & \\
\hline Balanus trigonus & & & $\mathrm{x}$ & & & & \\
\hline Chthamalus proteus & $\mathrm{XX} *$ & $\mathrm{XX}$ & & & & & \\
\hline Megabalanus tintinnabulum & $\mathrm{XX}$ & & & & & $\mathrm{x}$ & \\
\hline Tesseropora $\mathrm{sp}$ & $\mathrm{x}$ & & & & & & \\
\hline Caprella sp & & & $\mathrm{x}$ & & & & \\
\hline Amphipoda Gammaridae & & $\mathrm{X}$ & & & & & \\
\hline Tanaidacea & $\mathrm{x}$ & $\mathrm{x}$ & $\mathrm{x}$ & & & $\mathrm{XX} *$ & \\
\hline Pachygrapsus gracilis & & $\mathrm{XX} *$ & & & & $\mathrm{x}$ & \\
\hline Bowerbankia sp & $\mathrm{x}$ & & & & & & $\mathrm{XX}$ \\
\hline
\end{tabular}

As a general rule, these boats have several native species of the Pernambuco coast, present in the harbor basin and estuarine area of Recife and in the neighboring coastal reefs. The "Horizonte 1" fishing boat that had spent three months in the port after leaving the shipyard is an example of this. The "Zeus" tugboat moored in the Port since October 2003 and cleaned in March, showed several seaweeds with associated nemerteans, marine worms and Bowerbankia sp moss animals, after one month in operation in the harbor area.

\section{Brazilian Coastal Vessels}

This category includes 12 examined vessels that had been operating exclusively on the coastal trade, consisting of 2 research vessels, 1 dredger and 9 fishing boats. The fouling assemblages contained a total of 51 species, of which 18 species of Cirripedia, the most diverse taxa among the fouling species. Amphibalanus amphitrite, A. improvisus, Megabalanus tintinnabulum, Chthamalus proteus and Conchoderma virgatum were the dominant ones. Nine species, or $17.6 \%$ of the total community, are known to be invasive in some portion of their range and one, M. coccopoma, is considered a risk species (Table 4). Several species were at a reproductive stage, a fact observed mainly among the crustaceans.

The research vessels examined were the "Riobaldo" and "Natureza", belonging to the Center of Fishing Resources Research and Administration of the Northeast Littoral (CEPENE/IBAMA), placed in the Tamandaré Bay, south coast of Pernambuco, and used for assessments of the pelagic resources in the Northeastern Brazilian coast. The fouling fauna in these boats presented the typical marine organisms of 
the intertidal region of Brazilian littoral; the "Riobaldo" vessel showed the richest fouling community seen in this survey, with 24 species, in spite of belonging to the Environmental Ministry. An unidentified barnacle Tesseropora sp was also found on both research boats.

This category of vessels included five fishing boats called "Chung Kuo" (numbers 232, 242, 280, 287, and 289). Originally from Panama, Philippines and China (all the crews from Philippines), they have operated in the oceanic region of Brazil for seven months, according to the shipping agents that handled those vessels, between the Pernambuco and Pará States, Northeast and Northern regions of Brazil, respectively. This group of vessels showed the second richest fouling community, with 18 - 22 kinds of animals settled on each one, including a Tetraclitidae barnacle, found on the hull of two boats, settled in the crevice of the motor refrigeration water exit.

Table 4. Checklist of fouling species observed on the hulls of six vessels operating in the Brazilian coast. $\mathrm{X}=$ present, $\mathrm{XX}=$ numerically dominant on the vessel's hull; * in reproduction; Locals: $\mathrm{CE}=$ Ceará; $\mathrm{PB}=\mathrm{Paraíba}$; $\mathrm{PE}=\mathrm{Pernambuco}$; $\mathrm{RS}=\mathrm{Rio}$ Grande do Sul; $\mathrm{SP}=$ São Paulo States and $\mathrm{OC}=$ oceanic (North and Northeast Brazilian littoral).

\begin{tabular}{|c|c|c|c|c|c|c|c|c|c|c|c|c|}
\hline VESSEL & Natureza & Riobaldo & $\begin{array}{l}\text { Belém- } \\
\text { PA }\end{array}$ & $\begin{array}{c}\text { Chung } \\
\text { Kuo } \\
232 \\
\end{array}$ & $\begin{array}{c}\text { Chung } \\
\text { Kuo } \\
242 \\
\end{array}$ & $\begin{array}{c}\text { Chung } \\
\text { Kuo } \\
280 \\
\end{array}$ & $\begin{array}{c}\text { Chung } \\
\text { Kuo } \\
287 \\
\end{array}$ & $\begin{array}{c}\text { Chung } \\
\text { Kuo } \\
289 \\
\end{array}$ & $\begin{array}{c}\text { Gilontas } \\
168 \\
\end{array}$ & Ilária-CE & $\begin{array}{c}\text { Titan } \\
\text { Port } \\
\text { Zidan } \\
\end{array}$ & $\begin{array}{c}\text { Hang } \\
\text { Jun } \\
3001 \\
\end{array}$ \\
\hline TYPE & Research & Research & Fishing & Fishing & Fishing & Fishing & Fishing & Fishing & Fishing & Fishing & Fishing & Dredger \\
\hline LOCAL & PE & PE & PE & $\mathrm{OC}$ & $\mathrm{OC}$ & $\mathrm{OC}$ & OC & $\mathrm{OC}$ & PE & $\mathrm{CE}$ & RS & SP \\
\hline $\begin{array}{l}\text { Hydroida } \\
\text { Aiptasia } \\
\text { pallida } \\
\text { Distylochus } \\
\text { martae }\end{array}$ & & $\mathrm{X}$ & & $\mathrm{X}$ & $\mathrm{X}$ & & $\mathrm{X}$ & & & & & $\mathrm{X}$ \\
\hline Nematoda & $\mathrm{X}$ & $\mathrm{X}$ & & $\mathrm{X}$ & & $\mathrm{X}$ & & & & & $\mathrm{X}$ & \\
\hline Nemertea & & & & & & $\mathrm{X}$ & $\mathrm{X}$ & & & & & $\mathrm{X}$ \\
\hline Polychaeta & $\mathrm{X}$ & & & $\mathrm{X}$ & $\mathrm{X}$ & $\mathrm{X}$ & $\mathrm{x}$ & & & $\mathrm{X}$ & & \\
\hline $\begin{array}{l}\text { Hydroides sp } \\
\text { Brachidontes }\end{array}$ & & & & & $\mathrm{X}$ & $\mathrm{X}$ & $\mathrm{x}$ & & & & & $\mathrm{X}$ \\
\hline $\begin{array}{l}\text { exustus } \\
\text { Brachidontes } \\
\text { solisianus } \\
\text { Crassostrea }\end{array}$ & $\mathrm{X}$ & & & & $\mathrm{X}$ & $\mathrm{X}$ & & & & & & \\
\hline $\begin{array}{l}\text { Crassoshrea } \\
\text { rhizophorae } \\
\text { Isognomon }\end{array}$ & & $\mathrm{x}$ & & & & & & & & $\mathrm{x}$ & & $\mathrm{X}$ \\
\hline $\begin{array}{l}\text { bicolor } \\
\text { Mytella }\end{array}$ & & $\mathrm{X}$ & & & $\mathrm{X}$ & & & & & & & $\mathrm{X}$ \\
\hline $\begin{array}{l}\text { charruana } \\
\text { Mytilopsis } \\
\text { leucophaeta }\end{array}$ & & $\mathrm{X}$ & & $\mathrm{X}$ & & $\mathrm{X}$ & $\mathrm{x}$ & & & & & \\
\hline $\begin{array}{l}\text { Ostrea } \\
\text { equestris } \\
\text { Colisella }\end{array}$ & & $\mathrm{X}$ & & & $\mathrm{X}$ & & & & & & & \\
\hline $\begin{array}{l}\text { subrugosa } \\
\text { Littorina } \\
\text { angulifera }\end{array}$ & $\mathrm{X}$ & & $\mathrm{X}$ & & & & & & & & & \\
\hline $\begin{array}{l}\text { Littorina flava } \\
\text { Nodilittorina } \\
\text { ziczac } \\
\text { Melanoides } \\
\text { tuberculata }\end{array}$ & $\mathrm{x}$ & & $\mathrm{x}$ & & & & & & & $\mathrm{X}$ & & \\
\hline Neritina zebra & & & & $\mathrm{X}$ & & & & & & & & \\
\hline Vermetidae & & & & & & $\mathrm{X}$ & & & & & & \\
\hline Chironomidae & & & & & & & & & & & $\mathrm{x}$ & \\
\hline $\begin{array}{l}\text { Pycnogonida } \\
\text { Amphibalanus }\end{array}$ & & & & $\mathrm{X}$ & $\mathrm{X}$ & & & & & & & \\
\hline $\begin{array}{l}\text { amphitrite } \\
\text { Amphibalanus }\end{array}$ & & $\mathrm{X}$ & & $\mathrm{X}$ & $\mathrm{X}$ & $\mathrm{x}$ & $\mathrm{XX}$ & & & & $\mathrm{X}$ & $\mathrm{X}$ \\
\hline $\begin{array}{l}\text { eburneus } \\
\text { Amphibalanus }\end{array}$ & & & & $\mathrm{X}$ & $\mathrm{x}$ & $\mathrm{x}$ & & & & & & $\mathrm{X}^{*}$ \\
\hline $\begin{array}{l}\text { improvisus } \\
\text { Amphibalanus }\end{array}$ & & $\mathrm{XX}$ & & $\mathrm{X}$ & $\mathrm{x}$ & $\mathrm{XX}^{*}$ & $\mathrm{XX}$ & & & & $\mathrm{X}$ & $\mathrm{XX} *$ \\
\hline $\begin{array}{l}\text { reticulatus } \\
\text { Amphibalanus }\end{array}$ & & $\mathrm{XX}^{*}$ & & $\mathrm{X}$ & & $\mathrm{X}$ & $\mathrm{XX}$ & & & & & $\mathrm{X}$ \\
\hline $\begin{array}{l}\text { subalbidus } \\
\text { Aiptasia }\end{array}$ & & & & & & & & & & & & $\mathrm{X}^{*}$ \\
\hline $\begin{array}{l}\text { pallida } \\
\text { Distylochus } \\
\text { martae }\end{array}$ & & $\mathrm{XX}$ & & $\begin{array}{l}X \\
X\end{array}$ & $\mathrm{x}$ & & & & & & & \\
\hline Nematoda & $\mathrm{X}$ & $\mathrm{X}$ & & $\mathrm{X}$ & & $\mathrm{x}$ & & & & & $\mathrm{x}$ & \\
\hline
\end{tabular}


Table 4. (continued)

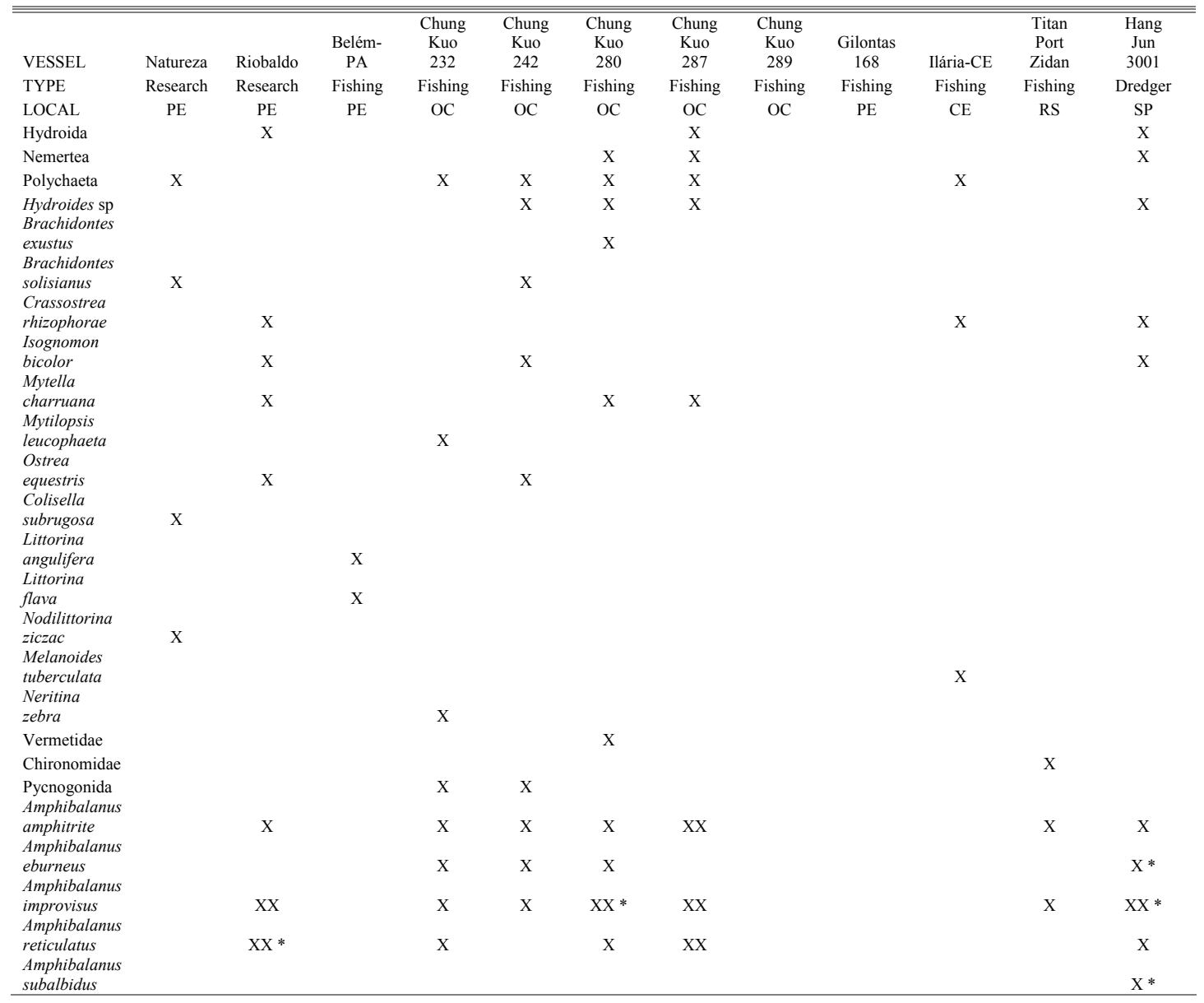

The Lepadomorpha barnacles, mainly Lepas anatifera and $L$. hillii, were common on almost all fishing boats, including the "Titan - Port Zidan", from Rio Grande do Sul, in the extreme Southern region of Brazil, which also carried dead specimens of Megabalanus coccopoma.

The "Hang Jun 3001" dredger vessel that came from Santos (São Paulo State- Southwest region of Brazil) and which dredged muddy sediments at the Port of Recife for three months (October to December 2005), brought several species on its hull, including the barnacle Amphibalanus subalbidus (in reproduction - with eggs incubated in the mantle cavity) and the purse-oyster Isognomon bicolor.

Vessels Navigating Between Recife and the Atlantic Brazilian Archipelagos

Several inspections were made on five cargo vessels and 1 fishing boat operating between the Port of Recife and the archipelagos of Fernando de
Noronha (Pernambuco) and São Pedro e São Paulo, both in the Atlantic Ocean (Table 5). Some mollusks (especially Brachidontes solisianus, Mytilopsis leucophaeta, Littorina angulifera and L. flava) and barnacles (mainly Amphibalanus amphitrite, $A$. eburneus, A. improvisus, and A. reticulatus), belong to the estuarine community of the harbor area; the lepadomorphs Conchoderma auritum, C. virgatum, Lepas anatifera, L. anserifera and $L$. hillii are considered typically oceanic.

With 21 islands, the Archipelago of Fernando de Noronha $\left(3^{\circ} 54^{\prime} \mathrm{S}\right.$ and $\left.32^{\circ} 25^{\prime} \mathrm{W}\right)$ has an area of $26 \mathrm{~km}^{2}$, about $545 \mathrm{~km}$ from Recife, capital of the State of Pernambuco, and $360 \mathrm{~km}$ to Natal, Rio Grande do Norte State. Its principal island is the only one inhabited, in part occupied by the Fernando de Noronha National Marine Park, considered an Environmental Protection Area (APA) since 1988. The Archipelago São Pedro e São Paulo, formed by 5 bigger islands and several other minor ones is an 
isolated group of barren islets $\left(0^{\circ} 55^{\prime} \mathrm{N}, 29^{\circ} 21^{\prime} \mathrm{W}\right)$, approximately $960 \mathrm{~km}$ from the Cabo de São Roque, Rio Grande do Norte, in the northeast coast of Brazil, and $650 \mathrm{~km}$ from the southwest of the Fernando de Noronha Archipelago (Edwards \& Lubbock, 1983), is maintained by the Brazilian Navy. Both these archipelagos are formed by the mountain peaks of a volcanic cordillera, with its base located about 4,000 $\mathrm{m}$ deep, part of the mid-Atlantic ridge.

Nineteen fouling species were found on the five Fernando de Noronha Archipelago cargo boats that stayed at the Port of Recife for approximately 3 days. On two vessels ("Concórdia" and "Burra Leiteira II"), several barnacles specimens (Amphibalanus amphitrite) and Tanaidacea were found in reproduction (with incubated eggs).

From the Archipelago São Pedro e São Paulo, only the "Águas do Rio Negro" fishing boat was investigate. This boat stayed there $30-45$ days, and in the Port of Recife 4 - 6 days. Ten animals were sampled from this boat, including the grapsid crab Plagusia depressa (2-3 specimens, all young, in all samples) and the lepadomorph barnacles.

Table 5. Checklist of fouling species observed on the hulls of six vessels operating in the Brazilian Archipelagos of Fernando de Noronha (FN) and São Pedro e São Paulo (ASPSP). X = present, XX = numerically dominant on the vessel's hull.

\begin{tabular}{|c|c|c|c|c|c|c|}
\hline VESSEL & $\begin{array}{c}\text { Águas do } \\
\text { Rio Negro } \\
\text { ASPSP }\end{array}$ & $\begin{array}{c}\text { Burra Leiteira } \\
\text { FN }\end{array}$ & $\begin{array}{c}\text { Burra Leiteira } \\
\text { II } \\
\text { FN }\end{array}$ & $\begin{array}{l}\text { Concórdia } \\
\text { FN }\end{array}$ & $\begin{array}{c}\text { Jaqueline III } \\
\text { FN }\end{array}$ & $\begin{array}{c}\text { Poty Boat } \\
\text { FN }\end{array}$ \\
\hline TYPE & Fishing & Cargo & Cargo & Cargo & Cargo & Cargo \\
\hline Hydroida & & & $\mathrm{x}$ & $\mathrm{x}$ & & \\
\hline Distylochus martae & & & $\mathrm{x}$ & $\mathrm{x}$ & & \\
\hline Nemertea & & $\mathrm{x}$ & $\mathrm{x}$ & & & \\
\hline Polychaeta & & & $\mathrm{x}$ & & $\mathrm{x}$ & \\
\hline Littorina angulifera & $\mathrm{x}$ & & $\mathrm{x}$ & & & $\mathrm{x}$ \\
\hline Littorina flava & $\mathrm{x}$ & & & & & $\mathrm{x}$ \\
\hline Crassostrea rhizophorae & & & $\mathrm{x}$ & & & \\
\hline Brachidontes solisianus & & & $\mathrm{x}$ & & & \\
\hline Mytella charruana & & $\mathrm{x}$ & $\mathrm{x}$ & $\mathrm{x}$ & & \\
\hline Mytilopsis leucophaeta & & & $\mathrm{xx}$ & $\mathrm{xx}$ & & \\
\hline Amphibalanus amphitrite & & & $\mathrm{x}$ & $x *$ & $\mathrm{x}$ & $\mathrm{x} *$ \\
\hline Amphibalanus eburneus & & & & $\mathrm{x}$ & & \\
\hline Amphibalanus improvisus & $\mathrm{x}$ & $\mathrm{x}$ & $\mathrm{xx}$ & $\mathrm{xx}$ & $\mathrm{xx}$ & \\
\hline Balanus trigonus & & $\mathrm{x}$ & & & & \\
\hline Lepas anatifera & $\mathrm{x}$ & & & & & \\
\hline Lepas anserifera & $\mathrm{x}$ & & & & & \\
\hline Lepas hillii & $\mathrm{x}$ & & & & & \\
\hline Amphipoda Gammaridae & & $\mathrm{x}$ & $\mathrm{x}$ & & & \\
\hline Isopoda Flabellifera & & & $\mathrm{x}$ & & & \\
\hline Ligia exotica & $\mathrm{x}$ & & & & $\mathrm{x}$ & \\
\hline Tanaidacea & & & $\mathrm{x} *$ & & $\mathrm{x}$ & \\
\hline Aratus pisonii & $\mathrm{x}$ & & & & & \\
\hline Pachygrapsus gracilis & $\mathrm{x}$ & & & & & \\
\hline Plagusia depressa & $\mathrm{x}$ & & & $\mathrm{x}$ & & \\
\hline
\end{tabular}


Foreign Routes/shipping

These analyses included the international voyages (between countries and oceans) with animals belonging to fourteen species. Heavy fouling of Hydroides sp was observed on two cargo ships from Panama, and a sail ship from temperate North Atlantic was marked by the presence of lepadomorph barnacles and one species of acorn barnacle (Table 6).

Table 6. Checklist of fouling species observed on the hulls of three vessels operating internationally. $\mathrm{X}=$ present, $\mathrm{XX}=$ observed as numerically dominant on the vessel's hull.

\begin{tabular}{lccc}
\hline \hline VESSEL & Götheborg & Steel 1 & Ruby I \\
\hline TYPE & Sailboat & Cargo & cargo \\
\hline ORIGIN & Swedish & Panama & Panama \\
\hline Distylochus martae & & $\mathrm{X}$ & \\
Polychaeta unident. & & $\mathrm{X}$ & \\
Hydroides sp & & $\mathrm{XX}$ & $\mathrm{XX}$ \\
Ostrea equestris & & $\mathrm{X}$ & \\
Amphibalanus amphitrite & & $\mathrm{XX}$ & \\
Amphibalanus improvisus & $\mathrm{XX}$ & $\mathrm{XX}$ & \\
Amphibalanus reticulatus & & $\mathrm{X}$ & \\
Balanus trigonus & & $\mathrm{X}$ & \\
Megabalanus coccopoma & & $\mathrm{XX}$ & \\
Conchoderma virgatum & $\mathrm{XX}$ & & \\
Lepas anatifera & $\mathrm{XX}$ & & \\
Lepas anserifera & $\mathrm{X}$ & & \\
Lepas hillii & $\mathrm{XX}$ & & \\
Alcirona sp & & $\mathrm{X}$ & \\
\hline
\end{tabular}

This category included the Swedish sailing ship "Götheborg", that had departed from the city of Götheborg on 2 October 2005, routing to Spain through the Channel, with a stop in Vigo of about 30 days, and then mooring in Cádiz, with 12 days stop. From Spain, this ship sailed south and then west crossing the Atlantic and passing the Equator to Recife, in Brazil. The trans-Atlantic part of the route took about 30 days. This ship brought only lepadomorph barnacles: Conchoderma virgatum, Lepas anatifera, L. anserifera, L. hillii and several recently-recruited Amphibalanus improvisus in the seaweed and settled on barnacle shells and stalk. None of the stalked barnacles examined had any sign of ovaries or ovigerous lamellae.

The "Ruby" cargo ship showed a fouling community dominated only by the annelid Hydroides $\mathrm{sp}$, with about $2 \mathrm{~m}$ of vertical range. A similar situation was seen on the "Steel 1" cargo ship, although other organisms were also found, mainly in the poop, near the screw propeller. These included the barnacles Amphibalanus improvisus and dead specimens of Megabalanus coccopoma.

\section{Discussion}

Non-indigenous marine species have been transported and introduced into new areas for as long as vessels with fouling organisms in their hulls have sailed between oceans (Coles et al., 1999). Skerman (1960) in his survey of marine fouling from vessels operating on a variety of routes in New Zealand waters, found several fouling species associated with vessels, showing the origin of ship-fouling as a port phenomenon, and with its regional interpretation based on the major trade routes. Since then several authors have surveyed the fouling communities associated with vessel's hulls with the aim of identifying nonindigenous species and monitoring their bioinvasion, (Coutts \& Taylor, 2005; Godwin, 2005). The amount of trans-oceanic shipping has increased greatly, and a tendency of modern vessels to move faster through the water may affect the survival and transport of fouling species and clinging requiring certain characteristics of the species. Furthermore, it may be considered that those species preferentially distributed on ships' hulls have had ample opportunity to spread, especially as some are now cosmopolitan in occurrence (Eno et al., 1997).

It was surprising to find sixty fouling species on vessels in the Port of Recife in spite of the advice control of International Maritime Organization (IMO) and the very wide use of anti-fouling techniques, including paints. The predominance of arthropods in the fouling community sampled here (including crustaceans $47 \%$ of the species and insect chironomids and pycnogonids, both representing $2 \%$ ) was also observed by Ray (2005), who observed respectively $27 \%, 20 \%$ and $6 \%$ for these taxa. Also Godwin (2003) observed that $35 \%$ of the hulls fouling species invaders to the Hawaiian isles were arthropods, against $16 \%$ and $13 \%$ of mollusks and polychaetes, respectively. The variety of animals sampled in this survey were similar in composition to the checklist of several authors, varying sometimes the species (but not the genus), except for the cosmopolitan species, mainly pan-tropical ones.

The Cirripedia, with nineteen species (fourteen acorn and five stalked barnacles) were the most diverse taxa among the fouling species. This group is also the most representative in almost all works elsewhere. Sampling on the 'Maui' oil platform, Forster \& Willan (1979) found twelve species of barnacles, eight balanomorphs and four lepadomorphs; these last ones represented by Conchoderma and Lepas genera, which are truly cosmopolitan and may breed and settle in particular water masses and be transported beyond favorable regions.

The similar composition of the fouling community on natural or artificial marine and estuarine intertidal and subtidal substrata in the harbor area and on the hull of boats moored for around 12 months was observed by Skerman (1960), who suggested that this fact provided the opportunity for a vessel to acquire all representative species. Carlton 
(1987) showed that the coastal ports and marinas act as hubs of domestic and international shipping movements. Floerl (2005) complemented this understanding saying that both the physical structure and the geographic location of port environments can influence fouling on the hulls of residence ships. As a result of the human-mediated introductions, the fauna of many harbor areas has become homogenized as native species are reduced in abundance and habitat breadth (Ruiz et al., 1997).

The finding that the pilot boats, tugboats and fishing boats limited to the neighborhood of the Port of Recife showed the same composition of the port is explained by Godwin (2003) who signalized that slow moving vessels that have long residence times in port and the vessels from decommission yards are more likely to develop fouling organisms than those that have short residence times and are transiting more often. It is a general experience that the prolonged immersion in the sea of a suitable substratum ultimately results in the development of a fouling assemblage, the structure of which is to some extent reproducible, stable, and characteristic of the locality observed (Skerman, 1960).

In relation of the vessels that navigate exclusively on the coastal trade, the fouling community can be separated in two types: the dredger community and that one settled on fishing and research boats. The dredger sampled in this last category showed high species diversity, mainly originally from the port area and coastal reefs of the Brazilian littoral, three of the species in reproduction stage. This result is different from that of Skerman (1960), who found that fouling from dredgers is not considered to be truly representative of the home port, since the silt-laden waters around an operating dredger probably impose some degree of selection on the survival of attached fouling organisms. The others boats of this category presented the richest number of species predominantly barnacles (eighteen species), several of them in reproduction. Baker et al. (2004) made similar observations based on the high numbers of private yachts and fishing vessels of the greater Tampa Bay area. Hull maintenance of yachts and fishing vessels is variable, records are spotty, regulations are non-existent, and movements by these vessels have been implicated in the intra-coastal spread of non-indigenous species. Typical groups of organisms, with many of the above-mentioned properties, did tend to develop upon vessels in the category under consideration as a result of complete or partial immobility or extended out-of-dock periods (Woods Hole Oceanographic Institution, 1952).

Higher vessel speeds, which sweep away most attached organisms, and antifouling paints have reduced hull fouling on major commercial vessels. Whilst as observed in this survey fouling can still occur on such vessels, in areas that lack antifouling paint or that are not swept directly by currents (Coutts \& Taylor, 2004). Hull fouling is now generally more important for other types of vessels. For example, oceanic barges move slowly, seldom have their hulls serviced, and spend weeks to months in each harbor. A single modern barge can have as much surface area as a fleet of 17th century galleons, and may support a dense and varied fouling community (Godwin \& Eldredge, 2001).

The presence of Striatobalanus amaryllis and Amphibalanus reticulatus on the hulls of tugboats out-docked since the decade of 1990 suggests shipborne introductions and appears to corroborate the arrival of these species at Pernambuco littoral in the Nineties, as pointed out by for that state. These species are considered as invaders, with potential to colonize new environments; $S$. amaryllis has been in the Brazilian littoral for at least 17 years (Neves \& Rocha, 2005), being found now amongst the species colonizing the Paranaguá Bay, in southern Brazil, as a result of intermediation of recreational vessels.

The species Amphibalanus subalbidus is currently found on most available substrata in brackish environments along the east coast of the United States, Trinidad, Gulf of Mexico, and in the northern Gulf of California region, indicating a naturally derived amphi-American distribution since the Mio-Pliocene (Van Syoc, 1992). Young (1994) found this species at Paraíba State (northeastern Brazil) and the arrival to the littoral of Pernambuco, a neighboring state, may have occurred through biofouling on fishing boats.

Another species that offers risk of bioinvasion in the northeast littoral of Brazil is Megabalanus coccopoma, found in two vessels that came to the Port of Recife, one from Panama, the other from Rio Grande do Sul (southern Brazil). This species is considered a nuisance fouler in Brazilian ports near and northward from Rio de Janeiro (Russell et al., 2004), where it may out-compete with the native congeneric, M. tintinnabulum, becoming dominant there (Young, 1994).

Finally, the number species associated to hulls of vessels that navigate between the Port of Recife and the Brazilian archipelagos is noteworthy, some of them well developed and at reproductive stage, which had never been cited as typical species from there.

This research showed that eleven taxa are involved in ship hull fouling in the Port of Recife comprising 28 sessile species, 8 sedentaries, and 23 free-living. The first observation of Conchoderma virgatum with exact location to the Brazilian littoral was recorded, and the first occurrence of Conchoderma auritum, Amphibalanus subalbidus and Haliplanella lineata to the littoral of Pernambuco 
State. In relation to the species already recorded for the estuarine area of Recife, it was confirmed that ship hull provided the pathway for the introduction of Amphibalanus reticulatus and Mytilopsis leucophaeta, invader species of the estuarine area of Recife City. The barnacle Megabalanus coccopoma was observed dead on two vessels and was considered to be a potential risk invader species for the region.

\section{REFERENCES}

BAKER, P.; BAKER, S. M.; FAJANS, J. Nonindigenous marine species in the greater Tampa Bay ecosystem Tampa Bay Estuary Program Tech. Publ., n. 02-04, 2004.

BOULTON, L. H.; POWELL, C. A.; HUDSON, W. B. Aspects of biofouling and corrosion on ship hulls clad with copper-nickel. In: ANNUAL CONFERENCE OF THE AUSTRALASIAN CORROSION ASSOCIATION, CORROSION AND PREVENTION 99, 1999, Sydney. Proceedings.... Sydney: the Australasian Corrosion Association., 1999. p 1-9.

CARLTON, J. T. Patterns of transoceanic marine biological invasions in the Pacific Ocean. Bull. Mar. Sci., v. 41, p. 452-465, 1987.

CARLTON, J. T.; GELLER, J. B. Ecological roulette: biological invasions and the global transport of nonindigenous marine organisms. Science, v. 261, p. 78-82, 1993.

CLARKE, A. Natural ways to banish barnacles. New Scient., v. 18, p. 38-41, 1995.

CLARKE, C. et al. Ballast water risk assessment, Port of Sepetiba, Federal Republic of Brazil. London: IMO, 2004. $99 \mathrm{p}$.

COELHO, P. A.; SANTOS, M. C. F. Ocorrência de Charybdis hellerii (Milne Edwards, 1867) (Crustacea, Decapoda, Portunidae) no litoral de Pernambuco. Bolm Téc.-Cient. CEPENE, v. 11, n. 1, p. 167-173, 2003.

COLES, S. L.; DEFELICE, R. C.; ELDREDGE, L. G. Nonindigenous marine species introductions in the harbors of the South and West shores of Oahu, Hawaii. Bishop Mus. Tech. Rep., v. 15, p. 1-228, 1999.

COUTTS, A. D. M.; TAYLOR, M. D. A preliminary investigation of biosecurity risks associated with biofouling on merchant vessels in New Zealand. New Zealand J. Mar. Freshw. Res., v. 38, n. 2, p. 215-229, 2004.

COUTTS, A. D. M.; TAYLOR, M. D. Biofouling on merchant vessels in New Zealand. In: GODWIN, L. S. ed. Hull fouling as a mechanism for marine invasive species introductions. Bishop Mus. Tech. Rep., 28: 1421. 2005.

DEFELICE, R. C.; ELDREDGE, L. G.; CARLTON, J. T. Nonindigenous invertebrates. In: ELDREDGE, L. G.; SMITH, C. M. A guidebook of introduced marine species in Hawaii. Bishop Mus. Tech. Rep., 21:70 p. 2001.

EDWARDS, A.; LUBBOCK, R. Marine zoogeography of Saint Paul`s Rocks. J. Biogeogr., v. 10, n. 65-72, 1983.

ENO, N. C.; CLARK, R. A.; SANDERSON, W. G. (Ed.). Non-native marine species in British waters: a review and directory. Peterborough: Joint Nature Conservation Committee, 1997. $136 \mathrm{p}$.
FLOERL, O. Factors that influence hull fouling on oceangoing vessels. In: Godwin, L. S. ed. Hull fouling as a mechanism for marine invasive species introductions. Bishop Mus. Tech. Rep., 28:6-13. 2005.

FOSTER, B. A.; WILLAN, R. C. Foreign barnacles transported to New Zealand on an oil platform. New Zealand J. Mar. Fresh. Res., v. 13, n. 1, p. 143-149, 1979.

GODWIN, L. S. Hull fouling of maritime vessels as a pathway for marine species invasions to the Hawaiian Islands. Biofouling, v. 19, p. 123-131, 2003. Supplement.

GODWIN, L. S. Maritime activities as a mechanism for introducing marine alien species: issues and management. IN: GODWIN, L. S. (Ed.) Hull fouling as a mechanism for marine invasive species introductions. Bishop Mus. Tech. Rep., 28:1-5. 2005.

GODWIN, L. S.; ELDREDGE, L. G. 2001. South Oahu marine invasions shipping study. Honolulu: Bishop Mus. Tech. Rep., 20:43 p.

GOLLASCH, S. The importance of ship hull fouling as a vector of species introductions into the North Sea. Biofouling, v. 18, n. 2, p. 105-121, 2002.

HEWITT, C. L. et al. Introduced and cryptogenic species in Port Phillip Bay, Victoria, Australia. Mar. Biol., v. 144, p. 183-202, 2004.

NEVES, C. S.; ROCHA, R. M. Bioinvasão mediada por embarcações de recreio na Baía de Paranaguá, PR e suas implicações para conservação. In: SIMPÓSIO BRASILEIRO SOBRE ESPÉCIES EXÓTICAS INVASORAS, 1., 2005, Brasília. Anais.... Brasília: MMA, IBAMA, 2005. v. 1.

PORT OF RECIFE. Informativos estatísticos. Recife, Agência Nacional de Transportes Aquaviários. Disponível em: <http://www.portodorecife.pe.gov.br>. Acesso em: 13 May 2006. 2006

RAY, G. L. Invasive estuarine and marine animals of the South Atlantic and Puerto Rico. ANSRP, Tech. Notes, v. 5 , n. 5 , p. $1-14,2005$.

RUIZ, G. M. et al. Global invasions of marine and estuarine habitats by non-indigenous species: mechanisms, extent, and consequences. Am. Zool., v. 37, p. 621-632, 1997.

RUIZ, G. M. et al. Global spread of microorganisms by ships. Nature, v. 408, p. 49-50, 2000.

RUSSEL, B. C.; NEIL, K.; HILLIARD, R. Ashmore Reef National Nature Reserve and Cartier Island Marine Reserve marine and terrestrial introduced species prevention and management strategy. Canberra: Department of Environment and Heritage, 2004. 18 p.

SKERMAN, T. M. Ship-fouling in New Zealand Waters: A survey of marine fouling organisms from vessels of the coastal and overseas trades. N. Z. Jl. Sci., v. 3, n. 4, p. 620-648, 1960.

SOUZA, J. R. B.; ROCHA, C. M. C.; LIMA, M. P. R. Ocorrência do bivalve exótico Mytilopsis leucophaeta (Conrad) (Mollusca, Bivalvia), no Brasil. Rev. Bras. Zool., v. 22, n. 4, p. 1204-1206, 2005.

TAVARES, M.; MENDONÇA JR, J. B. Charybdis hellerii (A. Milne-Edwards, 1867) (Brachyura, Portunidae), eighth nonindigenous marine decapod recorded from Brazil. Crustacean Res., v. 25, p. 151-157, 1996.

TORCHIN, M. E.; LAFFERTY, K. D.; KURIS, A. M. Release from parasites as natural enemies: increased 
performance of a globally introduced marine crab. Biol. Invasions, v. 3, p. 333-345, 2001.

TORCHIN, M. E. et al. Introduced marine species and their missing parasites. Nature, v. 421, p. 628-630, 2003.

VAN SYOC, R. I. Living and fossil populations of a Western Atlantic barnacle, Balanus subalbidus Henry, 1974, in the Gulf of California region. Proc. San Diego Soc. Natl. Hist, n. 12, p. 1-7, 1992.

WASSON, K. et al. Biological invasions of estuaries without international shipping: the importance of intraregional transport. Biol. Conserv., v. 102, n. 2, p. 143-153, 2001.
WOODS HOLE OCEANOGRAPHIC INSTITUTION. Marine fouling and its prevention. Annapolis: United States Naval Institute, 1952. 338 p.

YOUNG, P. S. The Balanoidea (Cirripedia) from the Brazilian coast. Bolm. Mus. Nac., série Zoologia, v. 356, p. 1-36, 1994.

(Manuscript received 09 June 2006; revised 06 October 2006; accepted 08 May 2007) 